\title{
Migratory behaviour and ocean survival of escaped out-of-season smolts of farmed Atlantic salmon Salmo salar
}

\author{
Ove T. Skilbrei* \\ Institute of Marine Research, PO Box 1870 Nordnes, 5817 Bergen, Norway
}

\begin{abstract}
A large proportion of farmed Atlantic salmon Salmo salar L. smolts are produced under intensive rearing conditions. They reach smolt size and are transferred to net pens in seawater during their first autumn under a short natural daylength, instead of being synchronised with the natural period for seawater entry of wild smolts under increasing daylength the next spring. Escapes of cultured salmon may threaten the genetic integrity of wild salmon, but there is little information about the impact of escaped out-of-season smolts. Do they display normal migratory behaviour typical of spring smolts, and can they survive at sea and return as mature adults? To answer these questions, about 23000 spring smolts (1 yr old) and a similar number of autumn out-of-season smolts were tagged with T-bar anchor tags and released from net pens in Masfjord on the west coast of Norway in 2007, 2008 and 2009. A further 43 out-of-season smolts were equipped with acoustic transmitters in 2008. A quarter of the acoustically tagged smolts migrated rapidly out of the $22 \mathrm{~km}$ long fjord, while the rest disappeared in the fjord. Predation by pollack Pollachius pollachius contributed to this loss. One tagged out-of-season smolt $(0.004 \%$ recapture rate) and $39(0.17 \%)$ spring smolts were recaptured as adults. Escaped out-of-season smolts appear to be capable of normal smolt migratory behaviour if they escape during their first autumn, but their survival rate in the sea appears to be very low. The risks of negative environmental impacts are probably much lower for autumn smolts than for smolts that escape from net pens during spring and summer.
\end{abstract}

KEY WORDS: Out-of-season smolts - Escaped farmed salmon - Fish farms - Swimming speed · Ocean survival $\cdot$ Predation $\cdot$ Telemetry

\section{INTRODUCTION}

Due to the expansion in production of Atlantic salmon Salmo salar L. in net pens in seawater (Halwart et al. 2007) in the course of recent decades, the probability of impacts of farming on the environment is increasing. Negative impacts include release of waste effluents and nutrients from the cages (Ervik et al. 1994, Islam 2005), the spread of diseases and parasites (Finstad et al. 2000, Gargan et al. 2012), the attraction of wild species to fish farms (Dempster et al. 2009), and escapes of cultured individuals into the wild that may spawn and interfere with the genetic

*Email: ove.skilbrei@imr.no structure of wild salmon populations (Lura \& Sægrov 1991, McGinnity et al. 2003, Bourret et al. 2011, Glover et al. 2012).

Domesticated salmon are kept in freshwater in hatcheries from first feeding until the smolt stage, when they are normally transferred to larger production units in seawater. The smoltification process is the physiological and morphological transition that enables juvenile salmonids to switch from a freshwater-adapted metabolism to a marine pelagic lifestyle during spring (Hoar 1976, Gibson 1983) and summer (Antonsson \& Gudjonsson 2002). In culture, this process is stimulated and synchronised by in-

( ) The author 2013. Open Access under Creative Commons by Attribution Licence. Use, distribution and reproduction are unrestricted. Authors and original publication must be credited.

Publisher: Inter-Research 2013 ·www.int-res.com 
creasing daylength during spring (Stefansson et al. 1991). It has been demonstrated that farmed salmon that escape at the smolt stage in spring follow the natural migration pattern of wild fish and may return from the ocean as adults to spawn (Skilbrei 2010b). The spawning performance of these fish is believed to be more comparable to that of wild salmon than adult cultured salmon escaping just before spawning, which may suffer from competitive and reproductive inferiority resulting from domestication (Fleming et al. 1996, 1997). It is therefore a concern that escaped smolts may contribute to an undesirable introgression of escaped farmed salmon genetics into wild salmon populations.

Two decades ago, farmed smolts were normally transferred to net pens in seawater in the spring. Since then, however, production regimes have been accelerated by various innovations, and out-of-season smolts are produced for transfer to net pens during their first autumn (these fish are variously called $0+, \mathrm{S} 0, \mathrm{~S} 0+$, zero age, underyearling, off-season or autumn smolts). More rapid growth rates and the use of indoor long-short-long daylength photoperiod manipulation to adjust the timing of the smoltification process (Berge et al. 1995, Duston \& Saunders 1995, Skilbrei et al. 1997) have contributed to this development. Approximately $45 \%$ of the smolts in Norwegian salmon farms are currently out-of-season smolts transferred to net pens between August and December (data from 2006 to 2011, Norwegian Directorate of Fisheries; www.fiskeridir.no).

Migratory behaviour is evident in farmed Atlantic salmon smolts and post-smolts during spring and summer, but is gradually lost in cage-reared salmon over the course of the autumn (Skilbrei 2010a). The loss of migratory behaviour may be synchronised with the shortening of the natural daylength from summer to autumn. The hatchery photoperiod influenced the dispersion rate of experimentally escaped out-of-season smolts away from the release site in a release experiment (Uglem et al. in press), but the post-escape migratory behaviour of out-of-season smolts has not been studied in detail. It is not known whether they migrate as smolts in accordance with the stimulatory effect of the long daylength treatment they were given in the hatchery prior to the transfer, or if normal smolt behaviour is repressed because of the short daylength they encounter after being transferred to outdoor net pens in seawater. Furthermore, if they do migrate at this time of the season, just before conditions at sea become suboptimal as temperature drops and food availability declines during winter, can they survive in the wild until maturity? Rates of survival of released out-ofseason smolts have not been reported previously.

The present study reports a $3 \mathrm{yr}$ series (2007 to 2009) of tagging/release experiments performed in the small fjord Masfjord at the western coast of Norway to examine the survival to adulthood of farmed $1 \mathrm{yr}$ old spring smolts and out-of-season smolts that were experimentally released to the wild. The postrelease behaviour was studied by tagging smolts with acoustic transmitters in 2008. The behaviour of the spring smolts has been published previously (Skilbrei 2010a). The corresponding results for the out-of-season smolts are presented here.

\section{MATERIALS AND METHODS}

\section{Fish and tagging}

The fish were of the domesticated Aqua Gen strain that is widely used in Norwegian fish farming, and were produced at the hatchery at Matre Research Station (Institute of Marine Research). All the fish were first-fed in early March. The normal $1 \mathrm{yr}$ old smolts were reared indoors under continuous light until autumn, when they were moved to outdoor tanks where they were kept until the following spring. The zero-age autumn smolts were kept indoors, but the photoperiod was manipulated by using a long-short-long daylength treatment to synchronise and stimulate smoltification (Berge et al. 1995, Duston \& Saunders 1995). A reduction to $12 \mathrm{~h}$ of daily light is supposed to signal winter (Skilbrei et al. 1997), and this photoperiod was used for $6 \mathrm{wk}$ starting in July and followed by 6 to $8 \mathrm{wk}$ of continuous light before the smolts, silver in colour, were transferred to seawater. The first group of $1 \mathrm{yr}$ old smolts and autumn smolts that were produced each year were tagged in freshwater at the Matre Research Station, transferred to net pens in seawater 2 to $4 \mathrm{~d}$ later, and released 6 to $8 \mathrm{~d}$ after tagging from the fish farm where acoustic receiver no. 1 was located (Fig. 1). The next release group was transferred to $5.5 \times 5.5 \mathrm{~m}$ wide and $7 \mathrm{~m}$ deep net pens on the same dates as the first 2 groups and tagged in seawater 6 to $8 \mathrm{~d}$ before their respective releases (numbers and mean sizes of smolts and release dates are given in Table 1).

Apart from those equipped with acoustic transmitters ( $\mathrm{n}=43$, see next paragraph), all the fish were tagged with T-bar anchor tags (Hallprint). The letters HI (Norwegian acronym for the Institute of Marine Research; IMR), the IMR internet address (www. 


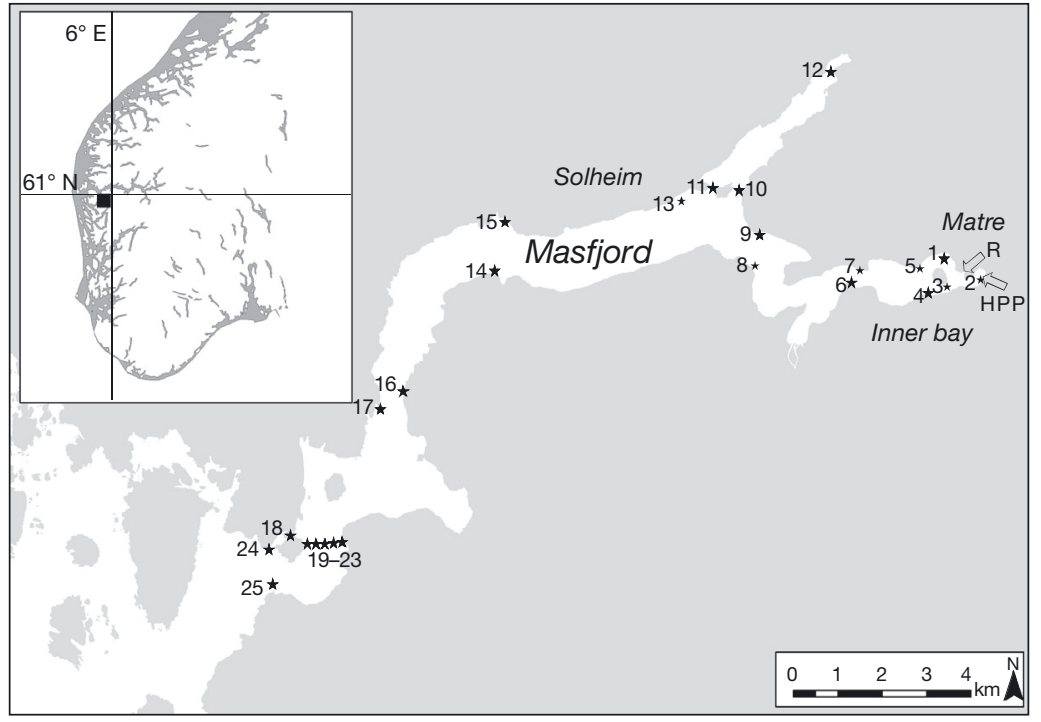

Fig. 1. Location of the acoustic receivers in Masfjord (1 to 25), Matre River (R) and the hydropower plant (HPP) in Norway. Receiver no. 1 is located at the fish farm at Matre (release site) and no. 13 at the other fish farm in the fjord at Solheim. The boundary of the inner bay area is marked by receiver nos. 6 and 7

imr.no) and postal code were printed on the T-bar tags in addition to an individual alphanumeric code.

Forty-three out-of-season smolts of 19.5 to $30.0 \mathrm{~cm}$ fork length from the 3 release groups of out-ofseason smolts in 2008 (Table 1) were tagged with 9 $\mathrm{mm}$ diameter telemetry transmitters with depth sensors (MP-9-Short, Thelma; length: $24 \mathrm{~mm}$, weight in water: $2.2 \mathrm{~g}$, min. to max. delay: 40 to $120 \mathrm{~s}$, expected battery life: $3.5 \mathrm{mo}$ ). The 1 yr old smolts and post-smolts were also tagged in 2008 (reported in Skilbrei 2010a). The fish were anaesthetised with a combination of benzocaine and metomidate. The concentration was adjusted until it took approximately 2 min to anaesthetise the fish. The intracoelomic surgical implantation of the transmitters was performed by a trained veterinarian. A $2 \mathrm{~cm}$ long incision was made in front of, slightly above, the left pelvic fin on the ventral surface of the fish. Terramycin ${ }^{\circledR}$ vet. (oxytetracycline) was dropped on the tag before inclusion. Tissue adhesive (Histoacryl ${ }^{\circledR}$ ) was added to the wound after 2 sutures had been closed (Supramid 2/0 polyamide monofilament) and tied with surgeon's knots. The equipment and needles were sterilised in $70 \%$ ethanol. The gills were irrigated once or twice during the operation, which took approximately $3 \mathrm{~min}$. The fish were first transferred to a tank supplied with running seawater for 0.5 to $1 \mathrm{~h}$ recovery, and then returned to the tank or net pen where the rest of the release group were held for $7 \mathrm{~d}$ before release. According to fish size, tag size was within the recommendations for their use to study

Table 1. Salmo salar. Dates of tagging and releases and numbers of 1 yr old (1+) and out-of-season smolts (0+) tagged with T-bar anchor tags and acoustic transmitters, as well as mean weight and fork length $( \pm \mathrm{SD})$ of release groups and length range (min. to max.) of acoustically tagged fish. Recapture rates of adult salmon (1 to 3 sea-winter salmon) are also shown. Blank: not applicable

\begin{tabular}{|c|c|c|c|c|c|c|c|c|c|c|}
\hline \multirow{2}{*}{$\begin{array}{l}\text { Smolt } \\
\text { age }\end{array}$} & \multirow[t]{2}{*}{ Tagging date } & \multirow[t]{2}{*}{ Release date } & \multicolumn{3}{|c|}{ T-bar anchor tags } & \multirow{2}{*}{$\mathrm{n}$} & \multicolumn{3}{|c|}{ Acoustic transmitters } & \multirow{2}{*}{$\begin{array}{c}\text { Recapture } \\
\% \text { (n) }\end{array}$} \\
\hline & & & $\mathrm{n}$ & $\begin{array}{l}\text { Length } \\
\text { (cm) }\end{array}$ & $\begin{array}{l}\text { Weight } \\
\text { (g) }\end{array}$ & & $\begin{array}{l}\text { Length } \\
\text { (cm) }\end{array}$ & $\begin{array}{l}\text { Length range } \\
\text { (cm) }\end{array}$ & $\begin{array}{l}\text { e Weight } \\
\text { (g) }\end{array}$ & \\
\hline \multicolumn{11}{|c|}{ Release year 2007} \\
\hline $1+$ & 23-24 May 2007 & 1 Jun 2007 & 4000 & $19.1 \pm 1.3$ & $77.1 \pm 13.5$ & & & & & $0.25(10)$ \\
\hline $1+$ & 26-27 Jun 2007 & 3 Jul 2007 & 3637 & $21.3 \pm 1.9$ & $108.9 \pm 27.6$ & & & & & $0.19(7)$ \\
\hline $0+$ & $17-18$ Oct 2007 & 25 Oct 2007 & 3989 & $20.8 \pm 1.1$ & $104.8 \pm 17.0$ & & & & & $0.03(1)$ \\
\hline $0+$ & 26 Nov 2007 & 3 Dec 2007 & 4260 & $23.7 \pm 1.5$ & $150.4 \pm 30.9$ & & & & & 0 \\
\hline \multicolumn{11}{|c|}{ Release year 2008} \\
\hline $1+$ & 7-9 May 2008 & 16 May 2008 & 3700 & $23.7 \pm 2.2$ & $153.1 \pm 40.0$ & & & & & $0.08(3)$ \\
\hline $1+$ & 18 Jun 2008 & 26 Jun 2008 & 2000 & $25.9 \pm 2.2$ & $185.0 \pm 47.5$ & & & & & $0.40(8)$ \\
\hline $0+$ & 16-17 Sep 2008 & 24 Sep 2008 & 3997 & $16.7 \pm 0.6$ & $57.3 \pm 6.5$ & 14 & $20.0 \pm 0.3$ & $19.5-20.6$ & $75.6 \pm 2.9$ & 0 \\
\hline $0+$ & $27-28$ Oct 2008 & 4 Nov 2008 & 2992 & $21.1 \pm 1.0$ & $106.5 \pm 16.9$ & 20 & $22.9 \pm 1.0$ & $21.3-26.0$ & $117.8 \pm 19.0$ & 0 \\
\hline $0+$ & 9-10 Dec 2008 & 17 Dec 2008 & 1790 & $26.4 \pm 1.1$ & $222.1 \pm 31.3$ & 9 & $28.2 \pm 1.4$ & $26.0-30.0$ & $228.0 \pm 26.6$ & 0 \\
\hline \multicolumn{11}{|c|}{ Release year 2009} \\
\hline $1+$ & 5 May 2009 & 15 May 2009 & 3997 & $23.0 \pm 2.5$ & $138.7 \pm 52.0$ & & & & & $0.18(10)$ \\
\hline $1+$ & 11 Jun 2009 & 18 Jun 2009 & 3999 & $24.2 \pm 2.5$ & $146.3 \pm 47.2$ & & & & & $0.03(1)$ \\
\hline $0+$ & 28-30 Oct 2009 & 7 Nov 2009 & 5945 & $20.5 \pm 0.8$ & $100.5 \pm 13.0$ & & & & & 0 \\
\hline \multicolumn{11}{|c|}{20808000} \\
\hline $0+$ & & & 22974 & $21.5 \pm 3.3$ & $123.6 \pm 56.6$ & & & & & $0.00(1)$ \\
\hline $1+$ & & & 23333 & $22.9 \pm 2.4$ & $134.9 \pm 37.4$ & & & & & $0.17(39)$ \\
\hline
\end{tabular}


swimming performance (Anglea et al. 2004, Lacroix et al. 2004), but 2 fish died during the first week after tagging and were excluded from the data analysis. All tags were tested immediately after the surgery, and there were daily recordings on receiver no. 1 for all the individuals that were held in a net pen during the week from tagging to release (the fish released on 4 November and 17 December 2007). The experiment and tagging procedures were approved by the Norwegian committee for the use of animals in scientific experiments (FDU), and permissions to release the fish were given by the Norwegian Directorate of Fisheries, the Norwegian Directorate for $\mathrm{Na}$ ture Management and the Norwegian Food Safety Authority.

\section{Location and validation of acoustic receivers}

Twenty-five acoustic receivers (VR2 and VR2W, Vemco) were positioned along Masfjord, with a higher density in the inner part of the fjord, and at the fjord mouth, $\sim 3 \mathrm{~km}$ before the fjord enters a larger, more open fjord system (Fig. 1). Receivers 6 and 7 marked the boundary of the 'inner bay area' (Fig. 1). The receivers were attached to floats moored to the bottom and kept at a depth of ca. $2 \mathrm{~m}$. The ability of the receivers to detect sonically tagged fish with high probability at the locations at which they were deployed had been confirmed in another telemetry experiment (Skilbrei 2010a) that studied the migration of $1+$ smolts and post-smolts that preceded and overlapped in time with the present study. That work demonstrated that up to $100 \%$ of the acoustically tagged smolts could be followed during their migration through and out of the fjord. It was concluded that the receiver coverage was sufficient to describe the movements of the fish within the fjord with a high degree of accuracy and that it was unlikely that fish could pass the outer transect of receivers unrecorded (receiver nos. 18 to 23) (Skilbrei 2010a).

\section{Hydrography}

The regulated Matre River and a hydroelectric power plant supply the inner bay of Masfjord with freshwater (Fig. 1), establishing a brackish surface layer which is typical of Norwegian fjords. Salinity and temperature profiles were recorded on 14 to $22 \mathrm{~d}$ per month at the fish farm at Matre from May 2008 to December 2008. At $4 \mathrm{~m}$ depth, the mean monthly salinity varied between 24.0 and 26.4. The mean temperature was $10.3^{\circ} \mathrm{C}$ in May and $13.3^{\circ} \mathrm{C}$ in June. A maximum mean temperature of $15.3^{\circ} \mathrm{C}$ was recorded for the last week of September 2008, after which it declined during autumn to $10.5^{\circ} \mathrm{C}$ in November and $9.5^{\circ} \mathrm{C}$ in December.

\section{Treatment of telemetry data}

To avoid false signals, single detections were not accepted unless there were additional recordings at the same or adjacent receivers during $1 \mathrm{~h}$. The fish were categorised into 3 groups: (1) fish that migrated out of the fjord, (2) fish that had presumably been preyed upon and (3) fish that disappeared in the fjord.

(1) Moved out of the fjord. I assumed that the fish that were detected at the receiver array at the fjord mouth (receivers 18 to 23) migrated out of the fjord. The direction of movement of $91 \%$ of these fish could be confirmed by means of additional recordings on the 2 outermost receivers (nos. 24 and 25).

(2) Preyed on. I assumed that smolts that increased swimming depth rapidly, and kept staying in deeper water away from the upper water column, had been taken by predators (Hedger et al. 2011). None of these fish moved considerably in the fjord after the shift in their depth-use pattern. With the exception of 1 individual that was recorded at receiver no. 13, they were only observed in the inner fjord at receiver nos. 1 to 7 (Fig. 1). Most of these tags (94\%) either moved very little between receivers or appeared to remain stationary. During the last weeks or months of the recordings, some stayed at a fixed depth as if they were resting on the seabed, while many $(50 \%$ of the predated fish) transmitted only error depth codes. These tags transmitted continuous sequences of the depth codes '127' or '255' (the maximum value), and some tags switched between these 2 codes. According to the producer, one possible reason for this malfunction may have been that the tags had been brought to depths greater than their maximum depth of $50 \mathrm{~m}$. The shifts in depth-use pattern occurred before the tags became stationary, so I assumed that predation was the most probable cause for the death of these fish.

(3) Disappeared. Tags that stopped transmitting signals and did not belong to the 'Preyed-on' group were categorised as 'Disappeared'. These fish may have died or been predated elsewhere in the fjord system, but losses due to tag malfunction is also possible. It was discovered in the above-mentioned other telemetry experiment that battery life was 
shorter than expected in some tags (Skilbrei 2010a). Tagged fish were recaptured after 3 to $4 \mathrm{wk}$. Some of the batteries were unexpectedly dead, and were tested by the manufacturer (Skilbrei 2010a). The tag manufacturer concluded that water may have penetrated into some tags and increased the consumption of current due to fissures that may have developed in the glue/casting material attaching the depth sensor unit. However, based on those experiences it is unlikely that a high percentage of the tags ran out of power, at least not during the first week after release.

The LOGISTIC procedure of SAS software package version 9.1 (SAS Institute) was used to fit generalised linear models (GLM) (McCullagh \& Nelder 1989), with a logistic link function to (1) test for differences in the probability of sonically tagged fish reaching the fjord mouth (binomial response variable) with time of release; and (2) to test whether the probability of recapture of T-bar-tagged adult salmon were influenced by smolt age and year of release.

$$
\begin{aligned}
& \text { Model 1: } \log [p /(1-p)]=I+A_{\text {group }} \\
& \text { Model 2: } \log [p /(1-p)]=I+B_{\text {age }}+C_{\text {year }}
\end{aligned}
$$

where $p$ is the probability, $I$ is the intercept, and $A_{\text {group }}, B_{\text {age }}$ and $C_{\text {year }}$ are the parameter estimates for the effects of release group (1,2 and 3), smolt age (0+ and 1+), and release year (2007, 2008 and 2009), respectively. The migration speeds of the groups of fish were compared using Student's $t$-test.

\section{RESULTS}

\section{Smolt movements}

A total of $44 \%$ of the smolts equipped with acoustic transmitters left the inner bay during the 3 first days post-release $(57 \%[n=8], 30 \%[n=6]$ and $56 \%$ [n = 5] of the fish released in September, November and December 2008, respectively). Most of them stayed in the inner bay approximately $1 \mathrm{~d}$ before moving outward, and with 1 exception, all the smolts that were detected at the outer receivers had left the fjord during the first week (Figs. 2 \& 3). The other sonically tagged individuals disappeared and/or were probably taken by predators in the inner bay area. Of the smolts that left the inner bay, $59 \%$ reached the fjord mouth $(26 \%$ of the total; Table 2$)$. The decline in the percentage of fish that moved out of the fjord with time of release (Table 2) was not significant (Model 1; Wald chi-squared $(W)=1.6, \mathrm{p}=0.4)$.

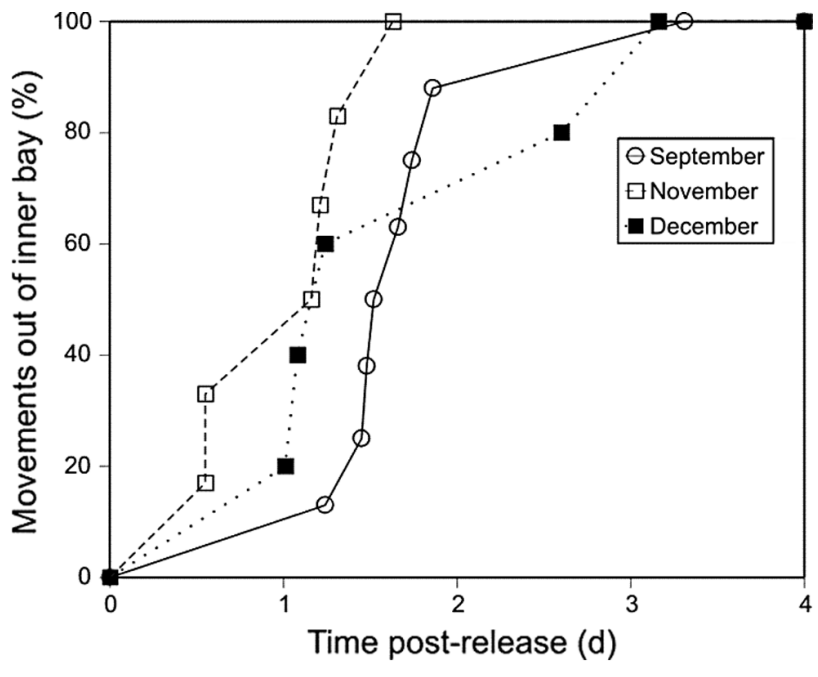

Fig. 2. Salmo salar. Timing of the descents from the inner fjord area plotted as the percentage of acoustically tagged out-of-season smolts moving out of the inner fjord area during the first $4 \mathrm{~d}$ following the 3 releases in September, November and December 2008. Fish that had presumably been taken by predators (see 'Materials and methods' for explanation) were not included in the analyses

The smolts of the first 2 release groups had an overall movement rate, i.e. from when they moved out of the inner bay until they left the fjord mouth, of $0.83 \pm$ $0.65(\mathrm{SD})(\mathrm{n}=5)$ and $0.70 \pm 0.51(\mathrm{n}=5)$ body lengths (bl) $\mathrm{s}^{-1}$ (not significant, $t$-test, $\mathrm{p}=0.72$ ). The single fish of the third release that migrated out of the fjord moved with a speed of $1.77 \mathrm{bl} \mathrm{s}^{-1}$. This gives a mean movement speed for all 3 releases of $0.86 \pm 0.61 \mathrm{bl} \mathrm{s}^{-1}$

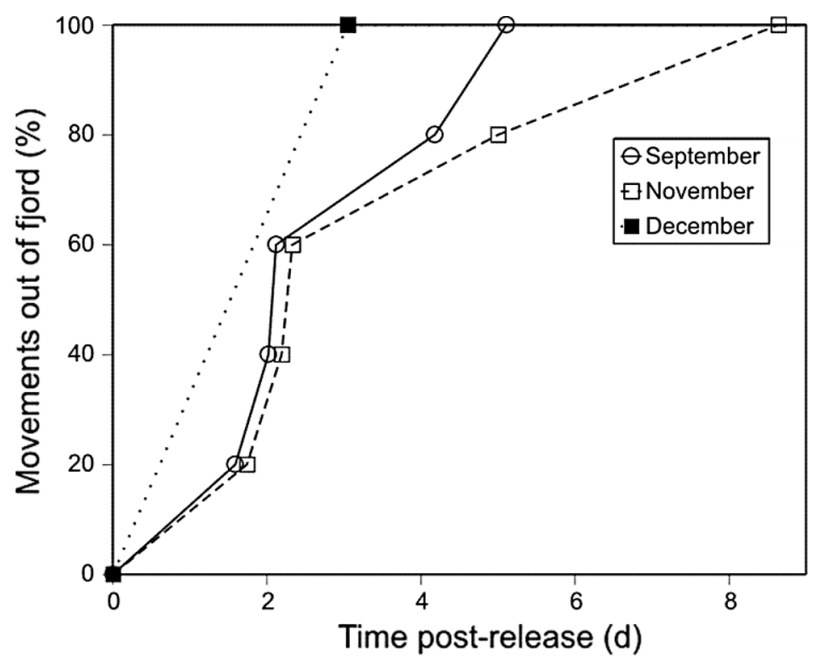

Fig. 3. Salmo salar. Timing of the migration out of Masfjord plotted as the percentage of acoustically tagged out-ofseason smolts leaving the fjord during the first $9 \mathrm{~d}$ following the 3 releases in September, November and December 2008.

Only successful migrants are included in the analyses 
Table 2. Salmo salar. Whereabouts of smolts equipped with acoustic transmitters following each of the 3 releases in 2008 (Table 1). Percentages (numbers given in parentheses) represent fish that either disappeared from the experiment, were assumed to have been taken by predators, or moved out of the fjord

\begin{tabular}{|lcccc|}
\hline Category & $\begin{array}{c}\text { Release } \\
\text { 24 Sep }\end{array}$ & $\begin{array}{c}\text { Release } \\
\text { 4 Nov }\end{array}$ & $\begin{array}{c}\text { Release } \\
\text { 17 Dec }\end{array}$ & Total \\
\hline $\begin{array}{l}\text { Disappeared } \\
\text { in inner bay }\end{array}$ & $29(4)$ & $10(2)$ & $0(0)$ & $14(6)$ \\
$\begin{array}{l}\text { Disappeared } \\
\text { elsewhere }\end{array}$ & $29(4)$ & $11(2)$ & $44(4)$ & $23(10)$ \\
$\begin{array}{l}\text { Preyed on } \\
\text { Moved out } \\
\text { of fjord }\end{array}$ & $76(1)$ & $55(11)$ & $44(4)$ & $37(16)$ \\
Total & $100(14)$ & $100(20)$ & $100(9)$ & $100(43)$ \\
\hline
\end{tabular}

( $\mathrm{n}=11)$. Several smolts turned and moved into the fjord before turning again and continuing in an outward direction. When summing up all recorded movements, both into and out of the fjord, then the average swimming speed was $1.37 \pm 0.68 \mathrm{bl} \mathrm{s}^{-1}(\mathrm{n}=5)$ for the first, and $0.98 \pm 0.45 \mathrm{bl} \mathrm{s}^{-1}(\mathrm{n}=5)$ for the fish of the second release group that reached the outer receivers ( $t$-test, $\mathrm{p}=0.31$ ).

The smolts that reached the fjord mouth swam at about the same depth $(1.6 \pm 0.5 \mathrm{~m}, \mathrm{n}=11)$ as those that disappeared between the inner bay and the fjord mouth $(1.7 \pm 0.9 \mathrm{~m}, \mathrm{n}=7)(t$-test, $\mathrm{p}=0.13)$. One tag that transmitted erroneous depth data during the movement from receivers 16 to 25 (Fig. 1) was excluded from the analysis.

\section{Disappearance of fish}

Sixteen individuals disappeared (Table 2) within the first $5 \mathrm{~d}$ post-release. Six of them were last detected in the inner bay (receivers 1, 3 and 5). Two of these disappeared on the day there were released, and the 4 others after 2, 3, 4 and 5 d post-release. Of the 10 individuals that disappeared elsewhere, 8 were last detected in the area from receiver nos. 7 to 13, and 2 disappeared after visiting receiver no. 17. They disappeared after $1 \mathrm{~d}$ (1 individual), $2 \mathrm{~d}$ (3 ind.), $3 \mathrm{~d}$ (4 ind.) and $4 \mathrm{~d}$ post-release ( 2 ind.).

\section{Smolt predation}

The proportion of 'Preyed-on' smolts increased and the 'Disappeared' group declined between the first and second releases (Table 2). Tags in smolts that were presumably captured by predators within the range of receivers showed a sudden increase in mean depth from $2.1 \pm 0.8 \mathrm{~m}$ to $12.1 \pm 8.0 \mathrm{~m}$. With one exception, smolts were taken by predators when they were within range of receivers 5 to 7 (Fig. 1), which were located close to known fishing locations for pollack Pollachius pollachius. For 12 of the smolts, a continuous series of recordings indicated the time of the sudden increase in depth, none of which occurred during daytime. Seven of these smolts appeared to be taken during late night and dawn (between 04:00 and 09:00 h), and the other 5 between 16:30 and 01:30 h. One of the tags presumably ingested by a predator described a consistent daily vertical rhythm during a period of $14 \mathrm{~d}$. It stayed at 20 to $22 \mathrm{~m}$ depth during daytime (from 08:00-09:00 $\mathrm{h}$ to 15:00-16:00 h) and at 3 to $6 \mathrm{~m}$ depth during twilight and night. Other tags moved between 5 and $25 \mathrm{~m}$ depth in a more irregular way, and some moved between 2 and $10 \mathrm{~m}$ depth with no apparent daily rhythm. The differing movement patterns according to depth suggest that different predator species may have been involved.

One professional fisherman who used gill nets in the fjord in the area between receivers 5 and 13 (see Fig. 1) returned $130 \mathrm{~T}$-bar tags found in stomachs of pollack; 12 and 63 tags from the 2 releases of out-ofseason smolts in 2007, 37 and 11 from the first 2 releases in autumn 2008, and 7 smolt tags from the autumn 2009 group. Thirteen pollack had 3 or 4 tags in their stomach (these accounting for one-third of all the tags found in stomachs). The fishing effort (soak times) of the gill nets is not known.

\section{Recaptures as adults}

One single out-of-season smolt was reported recaptured as an adult. It was $24.7 \mathrm{~cm}$ long when released on 3 December 2007, and weighted $3.9 \mathrm{~kg}$ when it was captured near the hydropower plant close to the release site (Fig. 1) 3 yr later, on 26 October 2010. Adult recaptures of the 1 yr old smolts were also low (39 individuals; Table 1), but significantly higher than those of out-of-season smolts (Model 2: $W=13.8, \mathrm{p}_{\text {smolt age }}<0.001 ; W=1.9, \mathrm{p}_{\text {release year }}=0.38$ ). Inclusion of a correction factor for tag loss $(5 \%$ per year) slightly increased the statistical differences between the treatment groups (Model 2: $W=15.7$, $\mathrm{p}_{\text {smolt age }}<0.0001 ; W=2.4, p_{\text {release year }}=0.30$ ). The sea age of the recaptured $1 \mathrm{yr}$ old smolts varied between 1 and $3 \mathrm{yr}(20.5 \%$ 1-sea-winter [1SW] salmon, $43.6 \%$ 2SW salmon and $35.9 \%$ 3SW salmon). 


\section{Mature male parr}

Fifty-eight previously mature male parr $(0.98 \%$ of the total release group) were found in the 2009 release group of out-of season smolts. They were significantly smaller than the immature smolts, $16.2 \pm$ $1.0 \mathrm{~cm}$ versus $20.5 \pm 0.8 \mathrm{~cm}$ ( $t$-test, $\mathrm{p}<0.0001)$. The mature male parr were classified by careful stripping. They had lost the parr marks and had obtained a silvery appearance, but had a yellowish hue that made them look less smoltified than the immature smolts. No mature male parr were found among the 2007 and 2008 out-of-season smolt release groups.

\section{DISCUSSION}

The out-of-season smolts released in September to December 2008 migrated at speeds of almost $1 \mathrm{bl} \mathrm{s}^{-1}$, which is similar to the speeds of spring smolts recorded by several other telemetry studies with cultured and wild smolts (Thorstad et al. 2004, 2007, Økland et al. 2006, Lacroix 2008), but slower than wild smolts in the northern Alta fjord (Davidsen et al. 2009). Compared to the 1 yr old spring smolts that were released from the same site in May and June 2008 (Skilbrei 2010a), the out-of-season smolts stayed a little longer in the inner bay before moving ( 24 h). However, when they left, they moved somewhat more slowly $\left(0.86 \mathrm{bl} \mathrm{s} \mathrm{s}^{-1}\right)$ than the smolts released in May $\left(1.36 \mathrm{bl} \mathrm{s}^{-1}\right)$, comparable with the June smolts $\left(0.78 \mathrm{bl} \mathrm{s}^{-1}\right)$, but very much faster than the post-smolts released in August, September and October (Skilbrei 2010a). At that time of the year, the post-smolts remained resident rather than migrating. Only 41, 6 and $0 \%$ of the post-smolts released in August, September and October, respectively, left the fjord during the first week (Skilbrei 2010a), and a high proportion stayed in the fjord for several months (Olsen \& Skilbrei 2010). This demonstrates that autumn smolts produced under an artificial longshort-long daylength regime developed and maintained the migratory behaviour typical of smolts for at least $6 \mathrm{wk}$ after they had been transferred to outdoor net pens in the sea under a natural short-day photoperiod. This conclusion differs from that of Uglem et al. (in press), who released out-of-season smolts in a large semi-enclosed sea bay and observed that the numbers of smolts recorded in the bay declined slowly during a $5 \mathrm{wk}$ period, probably due to a combination of migration and mortality.

The recapture rate of the out-of-season smolts was negligible, and significantly lower than the recapture of smolts released during spring and summer. This is in accordance with the expectation that the smolts that enter the sea during periods of suboptimal conditions suffer high rates of mortality. The out-ofseason autumn smolts are clearly out of phase with the natural life-cycle of salmon at sea. They enter open sea when production and temperature drop, and meet the coming winter with a very small body size compared to spring smolts, which have greatly increased their weight during the summer and autumn. It may also have contributed to the low survival rates of both the normal and the out-of-season smolts that the conditions in the North Atlantic ecosystem appear to have become less favourable for salmon during the past decade, and were probably not optimal during the experiments (Friedland et al. 2009, Otero et al. 2011, Skilbrei et al. 2013). The adult recapture rates were several times as high following the spring and summer releases of $1 \mathrm{yr}$ old smolts from the same release site in $2005(\sim 1 \%$; Skilbrei 2010b).

Predation was probably severe in Masfjord during the autumn. The pollack, which is the dominant fish predator in this fjord (Salvanes 1995), is evidently very capable of preying on salmon smolts. High losses of hatchery-reared fish after releases into the wild are common (Svåsand et al. 1998, Thorstad et al. 2011). However, predation in the fjord was probably much lower in May and June 2008, when all the acoustically tagged smolts survived the migration out of the fjord (Skilbrei 2010a), than in the period September to December 2008, when a high proportion were taken by predators within the fjord. It is possible that seasonal shifts in predator abundance were also of importance for the immediate post-release predation mortality in the present study. Besides, fishers in the fjord claim that pollack is more frequently caught close to the surface during autumn, so variability in the predation risk may possibly reflect seasonal trends in the vertical distribution of the predator.

Escapes of smolt and post-smolts during spring and summer are a hazard to the conservation of wild salmon populations (Skilbrei 2010b). The present study suggests that the risk of introgression with wild salmon is much lower after out-of-season smolts escape from net pens in seawater during autumn, since these smolts suffer high rates of mortality in the sea. One may also ask if early maturity may contribute to the environmental risks associated with escapements of out-of-season smolts. Mature male parr may develop during the production of out-of season smolts (Skilbrei \& Heino 2011), and were 
observed in one of the release groups in the present study. However, parr maturation and smolting are contrary processes with opposite biological functions (Evropeizeva 1958) and physiologies (Thorpe 1987), so it is unclear whether these males may still have the ability to return to freshwater and participate in spawning if they escape after they have been adapted to seawater. Further, Fjelldal et al. (2011) found jacks among out-of-season smolts that had been reared under elevated temperatures and continuous light in seawater in tanks, but observed no post-smolt maturity in groups held at a natural photoperiod in sea cages. If out-of-season smolts mature after escapement in late autumn, their maturation cycle would probably be delayed compared with the natural time for spawning in the rivers because of the previous photoperiod treatment. Although there may be some uncertainties about the possible role of early maturation, which may apply to out-of-season as well as to spring smolts, the probability of survival to adulthood appears to be clearly lower for the out-of-season smolts in the present study.

Acknowledgements. I am grateful to the staff at Matre Research Station for assisting with fish tagging, H. Sæbø for his skills in fish surgery, I. Sandnes for finding fish tags in pollack stomachs, O. R. Sandven for assisting with the map and H. M. Allen for comments on the paper. Financial support for the study was provided by the Institute of Marine Research and the Ministry of Fisheries and Coastal Affairs. I also thank 4 anonymous referees for their constructive criticisms and proposals for improvements of the paper.

\section{LITERATURE CITED}

> Anglea SM, Geist DR, Brown RS, Deters KA, McDonald RD (2004) Effects of acoustic transmitters on swimming performance and predator avoidance of juvenile Chinook salmon. N Am J Fish Manage 24:162-170

Antonsson T, Gudjonsson S (2002) Variability in timing and characteristics of Atlantic salmon smolt in Icelandic rivers. Trans Am Fish Soc 131:643-655

Berge ÅI, Berg A. Fyhn HJ, Barnung T, Hansen T, Stefansson SO (1995) Development of salinity tolerance in underyearling smolts of Atlantic salmon (Salmo salar) reared under different photoperiods. Can J Fish Aquat Sci 52:243-251

Bourret V, O'Reilly PT, Carr JW, Berg PR, Bernatchez L (2011) Temporal change in genetic integrity suggest loss of local adaptation in a wild Atlantic salmon (Salmo salar) population following genetic introgression by farmed escapees. Heredity 106:500-510

> Davidsen JG, Rikardsen AH, Halttunen E, Thorstad EB and others (2009) Migratory behaviour and survival rates of wild northern Atlantic salmon Salmo salar post-smolts: effects of environmental factors. J Fish Biol 75:1700-1718 > Dempster T, Uglem I, Sanchez-Jerez P, Fernandez-Jover D, Bayle-Sempere J, Nilsen R, Bjørn PA (2009) Coastal salmon farms attract large and persistent aggregations of wild fish: an ecosystem effect. Mar Ecol Prog Ser 385:1-14 > Duston J, Saunders RL (1995) Advancing smolting to autumn in age $0+$ Atlantic salmon by photoperiod, and long-term performance in sea water. Aquaculture 135: 295-309

> Ervik A, Thorsen B, Eriksen V, Lunestad BT, Samuelsen OB (1994) Impact of administering antibacterial agents on wild fish and blue mussels Mytilis edulis in the vicinity of fish farms. Dis Aquat Org 18:45-51

Evropeizeva NV (1958) Experimental analysis of the young salmon (Salmo salar L.) in the stage of transmission to life in the sea. Rapp P-V Reùn Cons Int Explor Mer 148: 129-139

> Finstad B, Bjørn PA, Grimnes A, Hvidsten NA (2000) Laboratory and field investigations of salmon lice [Lepeophtheirus salmonis (Krøyer)] infestation on Atlantic salmon (Salmo salar L.) post-smolts. Aquacult Res 31:795-803

Fjelldal PG, Hansen T, Huang Ts (2011) Continuous light and elevated temperature can trigger maturation both during and immediately after smoltification in male Atlantic salmon (Salmo salar). Aquaculture 321:93-100

> Fleming IA, Jonsson B, Gross MR, Lamberg A (1996) An experimental study of the reproductive behaviour and success of farmed and wild Atlantic salmon (Salmo salar). J Appl Ecol 33:893-905

> Fleming IA, Lamberg A, Jonsson B (1997) Effects of early experience on the reproductive performance of Atlantic salmon. Behav Ecol 8:470-480

Friedland KD, MacLean JC, Hansen LP, Peyronnet A and others (2009) The recruitment of Atlantic salmon in Europe. ICES J Mar Sci 66:289-304

> Gargan PG, Forde G, Hazon N, Russell DJF, Todd CD (2012) Evidence for sea lice-induced marine mortality of Atlantic salmon (Salmo salar) in western Ireland from experimental releases of ranched smolts treated with emamectin benzoate. Can J Fish Aquat Sci 69:343-353

Gibson RJ (1983) Water velocity as a factor in the change from aggressive to schooling behaviour and subsequent migration of Atlantic salmon smolts (Salmo salar). Nat Can 110:143-148

> Glover KA, Quintela M, Wennevik V, Besnier F, Sørvik AGE, Skaala Ø (2012) Three decades of farmed escapees in the wild: a spatio-temporal analysis of Atlantic salmon population genetic structure throughout Norway. PLoS ONE 7:e43129

Halwart M, Soto D, Arthur JR (2007) Cage aquacultureregional reviews and global overview. FAO Fish Tech Paper 498. FAO, Rome

> Hedger RD, Uglem I, Thorstad EB, Finstad B and others (2011) Behaviour of Atlantic cod, a marine fish predator, during Atlantic salmon post-smolt migration. ICES J Mar Sci 68:2152-2162

Hoar WS (1976) Smolt transformation; evolution, behaviour and physiology. J Fish Res Board Can 33:1233-1252

Islam MS (2005) Nitrogen and phosphorus budget in coastal and marine cage aquaculture and impacts of effluent loading on ecosystem: review and analysis towards model development. Mar Pollut Bull 50:48-61

$>$ Lacroix GL (2008) Influence of origin on migration and survival of Atlantic salmon (Salmo salar) in the Bay of Fundy, Canada. Can J Fish Aquat Sci 65:2063-2079

> Lacroix GL, Knox D, McCurdy P (2004) Effects of implanted dummy acoustic transmitters on juvenile Atlantic salmon. Trans Am Fish Soc 133:211-220 
Lura H, Sægrov H (1991) Documentation of successful spawning of escaped farmed female Atlantic salmon, Salmo salar, in Norwegian rivers. Aquaculture 98: 151-159

McCullagh P, Nelder J (1989) Generalized linear models, 2nd edn. Chapman \& Hall, New York, NY

McGinnity P, Prodöhl P, Ferguson A, Hynes R and others (2003) Fitness reduction and potential extinction of wild populations of Atlantic salmon, Salmo salar, as a result of interactions with escaped farm salmon. Proc R Soc Lond Biol Sci 270:2443-2450

Økland F, Thorstad EB, Finstad B, Sivertsgård R, Plantalech N, Jepsen N, McCinley RS (2006) Swimming speeds and orientation of wild Atlantic salmon post-smolts during the first stage of the marine migration. Fish Manag Ecol 13:271-274

> Olsen RE, Skilbrei OT (2010) Feeding preference of recaptured Atlantic salmon Salmo salar following simulated escape from fish pens during autumn. Aquacult Environ Interact 1:167-174

Otero J, Jensen AJ, L'Abée-Lund JH, Stenseth NC, Storvik GO, Vøllestad LA (2011) Quantifying the ocean, freshwater and human effects on year-to-year variability of one-sea-winter Atlantic salmon angled in multiple Norwegian rivers. PLoS ONE 6:e24005

Salvanes AGV (1995) Pollack (Pollachius pollachius) stock size development and potential influence on cod (Gadus morhua) mariculture in a west Norwegian fjord. Fish Res 24:223-242

Skilbrei OT (2010a) Reduced migratory performance of farmed Atlantic salmon post-smolts from a simulated escape during autumn. Aquacult Environ Interact 1: $117-125$

Skilbrei OT (2010b) Adult recaptures of farmed Atlantic salmon post-smolts allowed to escape during summer. Aquacult Environ Interact 1:147-153

Skilbrei OT, Heino M (2011) Reduced daylength stimulates size-dependent precocious maturity in 0+ male Atlantic salmon parr. Aquaculture 311:168-174

Editorial responsibility: Ian Fleming,

St. John's, Newfoundland and Labrador, Canada
Skilbrei OT, Hansen T, Stefansson SO (1997) Effects of decreases in photoperiod on growth and bimodality in Atlantic salmon Salmo salar L. Aquacult Res 28:43-49

Skilbrei OT, Finstad B, Urdal K, Bakke G, Kroglund F, Strand R (2013) Impact of early salmon louse (Lepeophtheirus salmonis) infestation, and differences in survival and marine growth of sea-ranched Atlantic salmon (Salmo salar) smolts 1997-2009. J Fish Dis 36: 249-260

Stefansson SO, Björnsson BT, Hansen T, Haux C, Taranger GL, Saunders RL (1991) Growth, parr-smolt transformation, and changes in growth hormone of Atlantic salmon (Salmo salar) reared under different photoperiods. Can J Fish Aquat Sci 48:2100-2108

Svåsand T, Skilbrei OT, Holm M, Van Der Meeren G (1998) Morphological and behavioural differences between reared and wild individuals: implications for sea-ranching with Atlantic salmon, Salmo salar L., Atlantic cod, Gadus morhua L., and European lobster, Homarus gammarus L. Fish Manag Ecol 5:473-490

Thorpe JE (1987) Smolting versus residency: developmental conflict in salmonids. Am Fish Soc Symp 1987:244-252

> Thorstad EB, Økland F, Finstad B, Sivertsgård R, Bjørn PA, McKinley RS (2004) Migration speed and orientation of Atlantic salmon and sea trout post-smolts in a Norwegian fjord system. Environ Biol Fishes 71:305-311

> Thorstad EB, Økland F, Finstad B, Sivertsgård R, Plantalech N, Bjørn PA, McKinley RS (2007) Fjord migration and survival of wild and hatchery-reared Atlantic salmon and wild brown trout post-smolts. Hydrobiologia 582:99-107

Thorstad EB, Uglem I, Arechavala-López P, Økland F, Finstad B (2011) Low survival of hatchery-released Atlantic salmon smolts during initial river and fjord migration. Boreal Environ Res 16:115-120

Uglem I, Økland F, Rikardsen A (in press) Early marine survival and movements of escaped Atlantic salmon Salmo salar L. parr and smolts from a land-based smolt farm during autumn. Aquacult Res doi:10.1111/j.1365-2109. 2012.03187.x

Submitted: August 28, 2012; Accepted: February 6, 2013 Proofs received from author(s): March 27, 2013 